\title{
ANALYSIS OF THE STRUCTURAL-DEFECT INFLUENCE ON THE MAGNETIZATION PROCESS IN AND ABOVE THE RAYLEIGH REGION
}

\author{
ANALIZA VPLIVA STRUKTURNIH DEFEKTOV NA PROCES \\ MAGNETIZACIJE V IN NAD RAYLEIGH PODROČJEM
}

\author{
Konrad Gruszka \\ Czestochowa University of Technology, Faculty of Production Engineering and Materials Technology, Institute of Physics, \\ Armii Krajowej Av. 19, 42-200 Czestochowa, Poland \\ kgruszka@wip.pcz.pl
}

Prejem rokopisa - received: 2015-06-30; sprejem za objavo - accepted for publication: 2015-09-16

doi: $10.17222 /$ mit.2015.154

\begin{abstract}
The paper presents studies of the structural-defect influence on the magnetization process in low magnetic fields $\left(H<0.4 H_{\mathrm{c}}\right)$ and above the Rayleigh range. The investigated $\mathrm{Fe}_{62} \mathrm{Co}_{10} \mathrm{Y}_{8} \mathrm{~B}_{20}$ alloy samples were obtained with the injection casting method resulting in the amorphous-structure state, which was confirmed with XRD. The studies were conducted by analyzing the disaccommodation of the magnetic-susceptibility process and using Kronmüller's theory in the approach to the ferromagnetic saturation area. On the basis of the obtained results, it was found that the main factor responsible for the processes of magnetization in low magnetic fields are point defects, whereas in the case of high magnetic fields, the magnetization process depends mainly on second-type pseudo-dislocation dipoles.

Keywords: metallic glasses, defects, disaccommodation, Kronmüller's theory

Članek predstavlja študij vpliva strukturnih defektov na proces magnetizacije v šibkem magnetnem polju $\left(H<0,4 H_{\mathrm{c}}\right)$ in nad Rayleigh področjem. Vzorci preiskovane zlitine $\mathrm{Fe}_{62} \mathrm{Co}_{10} \mathrm{Y}_{8} \mathrm{~B}_{20}$ so bili izdelani z metodo injekcijskega brizganja, kar je povzročilo amorfno strukturo, ki je bila potrjena z rentgensko analizo (XRD). Studije so bile izvedene $z$ analizo procesa neustreznosti magnetne občutljivosti in $\mathrm{z}$ uporabo Kronmülerjeve teorije pri približevanju feromagnetno nasičenemu področju. $\mathrm{Na}$ osnovi dobljenih rezultatov je bilo ugotovljeno, da so pri procesu magnetizacije glavni faktor točkaste napake, medtem ko je $\mathrm{v}$ primeru magnetizacije $\mathrm{v}$ močnem magnetnem polju proces odvisen predvsem od druge vrste psevdodislociranih dipolov.

Ključne besede: kovinska stekla, napake, neustreznost, Kronmüllerjeva teorija
\end{abstract}

\section{INTRODUCTION}

Iron-based amorphous materials are extensively studied because of their excellent soft-magnetic properties. ${ }^{1-3}$ For this reason, they have been widely used in the electrical industry, primarily as high-efficiency cores for power transformers and chokes and also as coatings due to their high corrosion resistance. ${ }^{4,5}$

In terms of topological structure, amorphous materials have properties similar to those of liquids. The atoms forming the material are scattered in a chaotic manner so that the observation of the long-range order is not possible. When the cooling rate of a liquefied alloy is sufficiently large, the kinetic energy of the atoms is taken so fast that they are trapped at higher energy positions. This results in the density and local chemical-composition fluctuations, and is the major cause of the areas with a deficiency of atoms. This type of local voids are called point defects (by analogy with the vacancies occurring in a crystal structure). In the cases where several point defects are located in a small local environment, a concentration to two-dimensional defects occurs and it is referred to as pseudo-dislocation dipoles.

Point defects and their conglomerates have a significant impact on the process of magnetization in high magnetic fields. ${ }^{6,7}$ The presence of structural defects, which are the centers of internal stresses, causes a deformation of local magnetization vectors. The presence of structural defects in amorphous materials affects the magnetization process in the area called the approach to ferromagnetic saturation. ${ }^{8}$ In close proximity to a point defect, the magnetization vectors are arranged in a "streamline" way ${ }^{9,10}$ which is a potential cause of domain-wall anchors. A more complicated situation occurs in the presence of a pseudo-dislocation dipole, where the arrangement of individual vectors is not collinear and the centers of the deformation of these vectors are hooked at the dipole ends. ${ }^{11-13}$

Ferromagnetic materials, especially the ones based on the Fe-Co-B composition are well known for their great soft-magnetic properties, in particular a low coercive field and magnetostriction while they are not expensive and have a high sensitivity to alloying additives. In the compounds of this type, iron is typically the major part (more than a $50 \%$ amount fraction) while Co, which has similar properties, allows an increase in the magnetization. Boron, due to a significant difference in the atomic radius, improves the glass-forming ability (GFA). In order to further increase the GFA, a small 
amount of yttrium atoms are introduced. According to the literature, a concentration of up to a $4 \%$ amount fraction has a positive effect on the GFA but exceeding this value brakes down good soft-magnetic properties. Using the studies on susceptibility-disaccommodation phenomena and approach to the ferromagnetic saturation area, it is possible to indirectly describe the structural defects existing in a material. This paper focuses on defects - the relations within a magnetization process and shows that despite an yttrium addition of up to $8 \%$, one can obtain reasonable results in terms of soft-magnetic parameters.

\section{STUDIED MATERIAL AND METHODOLOGY}

The investigated material comprises chemical elements of high purity ( $\mathrm{Fe}-$ a $99.95 \%$ amount fraction, the remaining component elements - $99.99 \%$ amount fractions). A two-step preparation procedure was used. Initially, the ingredients were melted using a plasma arc (a working current of $\sim 300 \mathrm{~A}$ ) under a reduced pressure in a protective atmosphere of argon. The samples were melted several times to ensure a good homogeneity of the constituent distribution. Then the resulting ingot was melted, using an induction furnace, in a quartz tube and injected into a copper water-cooled mold, which was also under an argon atmosphere (at a pressure of $700 \mathrm{hPa}$ ). In the radial cooling process, good-quality amorphous solid samples with dimensions of $15 \mathrm{~mm} \times 10 \mathrm{~mm} \times 0.5 \mathrm{~mm}$ were obtained. The structure of the obtained samples was examined using an X-ray diffractometer (Bruker D8 Advance, $\left.\mathrm{Cu}-K_{\alpha}\right)$. The magnetic properties were determined with an analysis of the static hysteresis loop and the initial magnetization curve, which were obtained from the measurements of the magnetization as a function of the magnetic-field strength using a vibrating sample magnetometer (model Lakeschore 7301). Measurements of the initial permeability of the samples were taken over a wide temperature range of $300-650 \mathrm{~K}$. The samples were suspended in a permalloy frame and placed in a quartz vacuum tube with a thermocouple, and the whole system was placed in an accumulative furnace. The disaccommodation-aftereffect intensity defined as $\Delta\left(\frac{1}{x}\right)=\frac{1}{\chi\left(t_{1}\right)}-\frac{1}{\chi\left(t_{0}\right)}$ was measured in time $\left(t_{1}-t_{0}\right)=118 \mathrm{~s}$

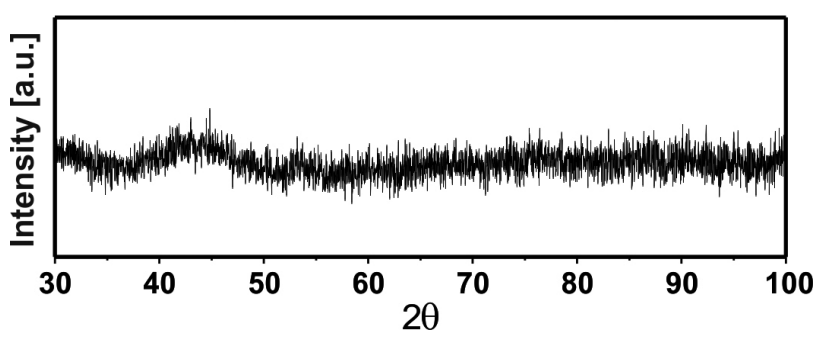

Figure 1: X-ray diffraction pattern of $\mathrm{Fe}_{62} \mathrm{Co}_{10} \mathrm{Y}_{8} \mathrm{~B}_{20}$ in the as-quenched state

Slika 1: Rentgenska difrakcija $\mathrm{Fe}_{62} \mathrm{Co}_{10} \mathrm{Y}_{8} \mathrm{~B}_{20}$ v kaljenem stanju with the transformer method. The frequency of the ac field was set to $50 \mathrm{~Hz}$. The samples were demagnetized by applying a sinusoidal decreasing magnetic field of $120 \mathrm{kHz}$.

\section{RESULTS}

Figure 1 shows the XRD of a sample after the solidification, measured for the $2 \theta$ angle in a range from $30^{\circ}$ to $100^{\circ}$.

The diffraction pattern shows only the broad fuzzy maximum, located in a $2 \theta$ angle range from approximately $35^{\circ}$ to $50^{\circ}$. This means that in a sample in the as-quenched state, there is no long-range order and the interactions between the atoms have a close- or medium-range character. Such a shape of a diffraction pattern is typical for the materials with an amorphous structure. Then measurements of the static magnetic hysteresis loop were carried out and the result is shown in Figure 2.

The observed shape of the curve is characteristic for a magnetic material with soft magnetic properties. Based on the analysis of the static magnetic hysteresis loop, the basic parameters for the magnetic sample were determined: magnetization saturation $M_{\mathrm{s}}=1.27(\mathrm{~T})$, coercive field $H_{\mathrm{c}}=289(\mathrm{~A} / \mathrm{m})$. Next, an analysis of the primary magnetization curve in the approach to the ferromagnetic saturation area was carried out. Figures 3 and $\mathbf{4}$ show magnetization curves as a function of $\left(\mu_{0} \mathrm{H}\right)^{-2}$ and $\left(\mu_{0} \mathrm{H}\right)^{1 / 2}$.

With respect to Kronmüller's theory, as a result of the analysis of the primary magnetization curve, it was found that in a $\mathrm{Fe}_{62} \mathrm{Co}_{10} \mathrm{Y}_{8} \mathrm{~B}_{20}$ alloy sample the magnetization process in the area called "Ewing's knee" relates to the change in magnetization vector directions caused by the presence of free-volume conglomerates. The linear-defect size $\left(D_{\text {dip }}\right)$ must therefore be larger than the exchange distance. Assuming that $D_{\text {dip }}>l_{\mathrm{H}}$, the $a_{2} /\left(\mu_{0} \mathrm{H}\right)^{2}$ law of approach to the ferromagnetic saturation area is

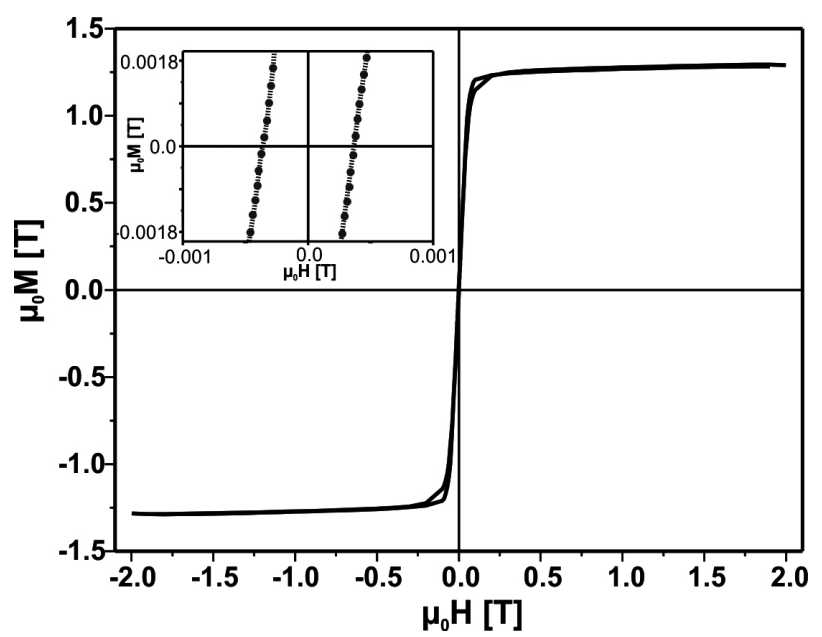

Figure 2: Static magnetic hysteresis loop for the $\mathrm{Fe}_{62} \mathrm{Co}_{10} \mathrm{Y}_{8} \mathrm{~B}_{20}$ alloy Slika 2: Statična magnetna histerezna zanka zlitine $\mathrm{Fe}_{62} \mathrm{Co}_{10} \mathrm{Y}_{8} \mathrm{~B}_{20}$ 


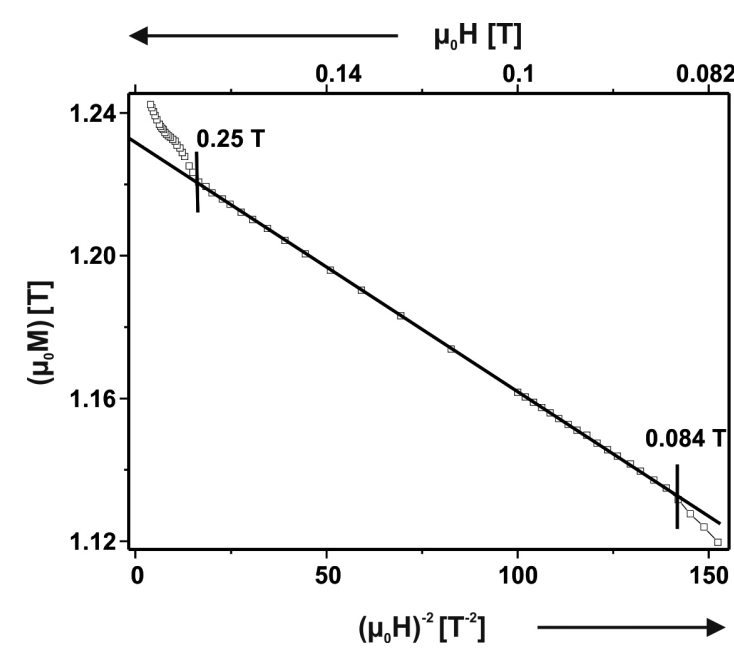

Figure 3: Magnetization as a function of $\left(\mu_{0} \mathrm{H}\right)^{-2}$ for the $\mathrm{Fe}_{62} \mathrm{Co}_{10} \mathrm{Y}_{8} \mathrm{~B}_{20}$ alloy

Slika 3: Magnetizacija kot funkcija $\left(\mu_{0} \mathrm{H}\right)^{-2}$ zlitine $\mathrm{Fe}_{62} \mathrm{Co}_{10} \mathrm{Y}_{8} \mathrm{~B}_{20}$

fulfilled. Thus, these defects are the main source of stress in the magnetic-field strength from $0.084(\mathrm{~T})$ to $0.25(\mathrm{~T})$. Above the $\left(\mu_{0} \mathrm{H}\right)^{-2}$ dependence, Holstein-Primakoff's process intensifies, indicating that the further process of magnetization is associated with the damping of thermally excited spin waves with an external magnetic field (the $b$ coefficient). The parameters obtained from the analysis of the primary magnetization curve are summarized in Table $\mathbf{1}$.

Table 1: Parameters obtained with the analysis of the primary magnetization curve

Tabela 1: Parametri, dobljeni z analizo primarne krivulje magnetizacije

\begin{tabular}{|c|c|c|c|c|}
\hline $\begin{array}{c}a_{2} \\
\left(10^{-2} \mathrm{~T}^{2}\right)\end{array}$ & $\begin{array}{c}b \\
\left(10^{-2} \mathrm{~T}^{1 / 2}\right)\end{array}$ & $\begin{array}{c}D_{\mathrm{sp}} \\
\left(10^{-2} \mathrm{meV} \mathrm{nm}^{2}\right)\end{array}$ & $\begin{array}{c}A_{\mathrm{ex}} \\
\left(10^{-12} \mathrm{~J} \mathrm{~m}^{-1}\right)\end{array}$ & $\begin{array}{c}l_{\mathrm{h}} \\
(\mathrm{nm})\end{array}$ \\
\hline 0.056 & 6.59 & 40.70 & 1.64 & 3.59 \\
\hline
\end{tabular}

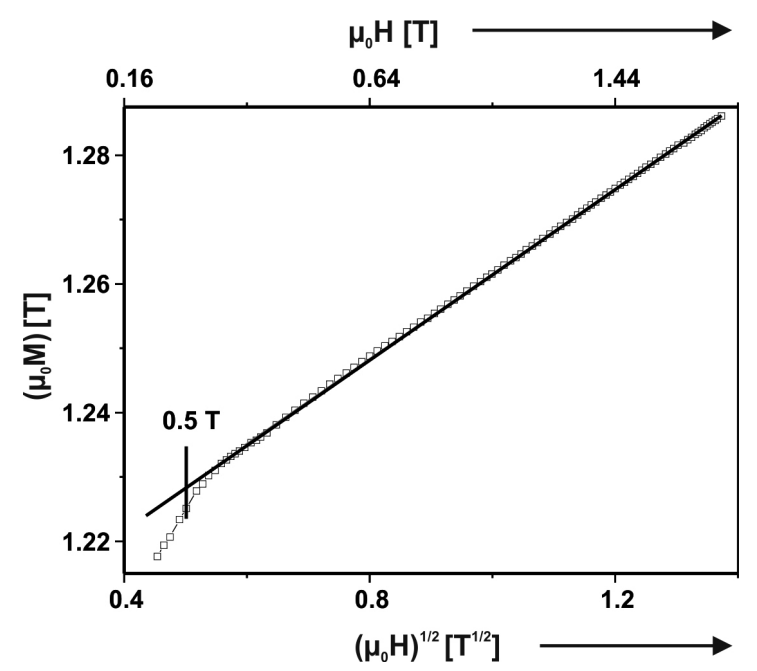

Figure 4: Magnetization as a function of $\left(\mu_{0} \mathrm{H}\right)^{1 / 2}$ for the $\mathrm{Fe}_{62} \mathrm{Co}_{10} \mathrm{Y}_{8} \mathrm{~B}_{20}$ alloy. Holstein-Primakoff process

Slika 4: Magnetizacija kot funkcija $\left(\mu_{0} \mathrm{H}\right)^{1 / 2}$ zlitine $\mathrm{Fe}_{62} \mathrm{Co}_{10} \mathrm{Y}_{8} \mathrm{~B}_{20}$. Proces Holstein-Primakoff

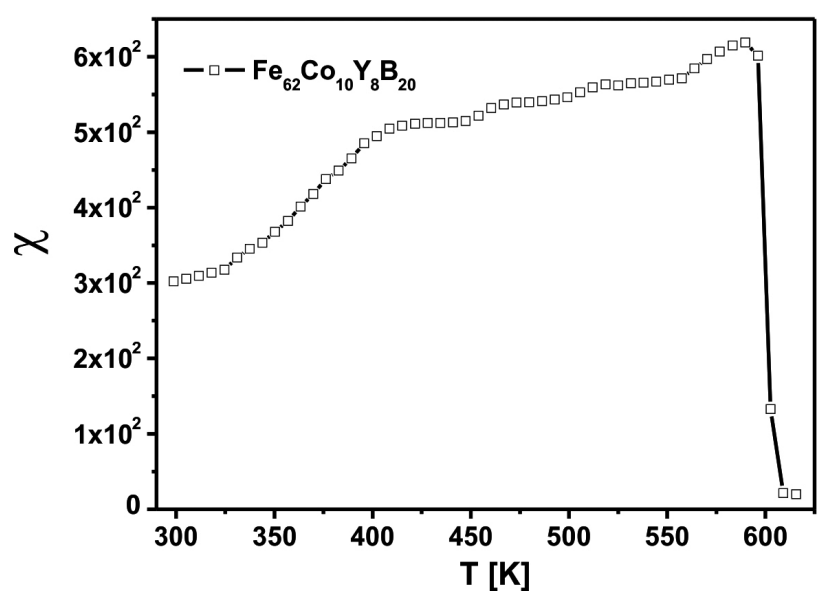

Figure 5: Dependence of the low-field magnetic susceptibility as a function of temperature for the $\mathrm{Fe}_{62} \mathrm{Co}_{10} \mathrm{Y}_{8} \mathrm{~B}_{20}$ sample

Slika 5: Odvisnost magnetne občutljivosti v šibkem polju od temperature vzorca $\mathrm{Fe}_{62} \mathrm{Co}_{10} \mathrm{Y}_{8} \mathrm{~B}_{20}$

The absence of the $a_{1 / 2}$ and $a_{1}$ factors indicate that the point defects and linear defects of a smaller size had no effect on the magnetization process in magnetic fields greater than $0.4 H_{\mathrm{c}}$ (above the Rayleigh region). This does not mean, however, that those defects are not present in the sample's structure but only that they are insignificant for the magnetization process. To investigate their potential impact on the magnetization at low fields, the susceptibility disaccommodation studies were conducted. According to Kronmüller's theory, it is possible to calculate the exchange distance of pseudo-dislocation dipoles (the $l_{\mathrm{h}}$ parameter) and the exchange-constant $\left(A_{\text {ex }}\right)$ parameter. The latter is responsible for transferring magnetic interactions between the nearest neighbors (the energy of aligned spins) and the former describes the size of a defect's influence zone. The $D_{\text {sp }}$ parameter, which describes the spin-wave stiffness (and, therefore, the ability to transfer the spin torque) is more than twelve times higher $\left(D_{\mathrm{sp}} / D_{\mathrm{Fe}}=12.96\right)$ than with pure $\mathrm{Fe}$ (the largest percentage share in the alloy), which is found to be between $D_{\mathrm{Fe}}=2.8 \mathrm{meV} \mathrm{nm}{ }^{2}$ at $4.2 \mathrm{~K}^{14}$ and $D_{\mathrm{Fe}}=$ $3.14 \mathrm{meV} \mathrm{nm}^{2}$ at room temperature. ${ }^{15}$ This parameter is connected with the atomic packing density (a higher $D_{\mathrm{sp}}$ means a higher surface density ${ }^{16}$ ) and it may indicate that linear defects should rather be considered as swellings of voids resulting in an increase in the local density around the defects, while keeping the overall material density low.

The thermal stability of the initial magnetic susceptibility was also investigated. This parameter is very important and often determines possible applications. For the studied sample, the shape of the dependency is shown in Figure 5.

Quite minor temperature-related changes in the value of the initial magnetic susceptibility were observed. A good stability and an almost linear growth may indicate that, in magnetic terms, the material is homogeneous and no other magnetic phases were formed (in accordance to 


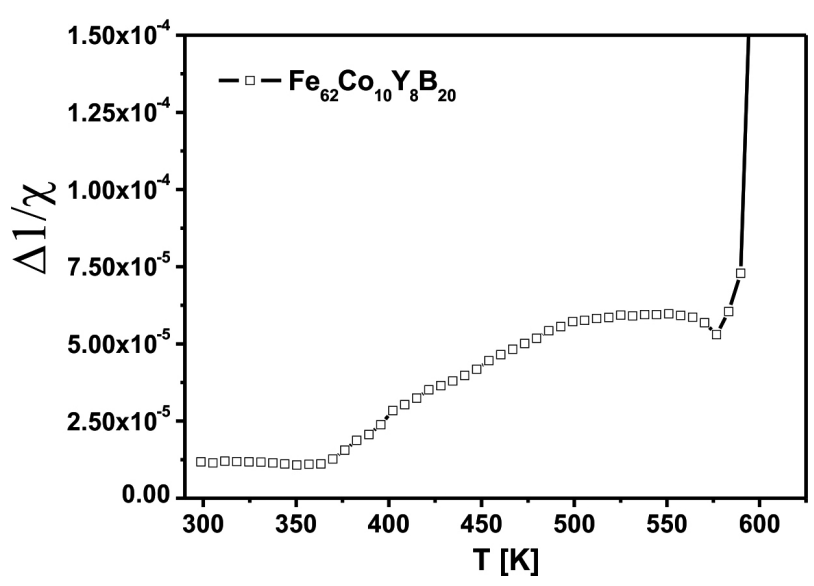

Figure 6: Magnetic-susceptibility disaccommodation curve for the $\mathrm{Fe}_{62} \mathrm{Co}_{10} \mathrm{Y}_{8} \mathrm{~B}_{20}$ alloy after solidification

Slika 6: Neprimerna krivulja magnetne občutljivosti zlitine $\mathrm{Fe}_{62} \mathrm{Co}_{10} \mathrm{Y}_{8} \mathrm{~B}_{20}$ po strjevanju

the XRD). Considering the rather low temperatures region, the conspicuous increase between $325 \mathrm{~K}$ and $400 \mathrm{~K}$ can be elucidated mainly with the sample's internaltension relaxation processes, together with a minor contribution of the magnetic-anisotropy reduction. The sharp decline observed near $600 \mathrm{~K}$ is associated with the paramagnetic transition when the ferromagnetic order is destroyed.

The time dependence of the initial susceptibility after the demagnetization at various temperatures, or the magnetic-susceptibility disaccommodation curve for the investigated alloy, is presented in Figure 6.

As can be seen in Figure 6, the disaccommodation intensity linearly rises up to the broad maximum located at about $542 \mathrm{~K}$. Above $542 \mathrm{~K}$, the intensity decreases, which is directly connected with the decrease in the amount of the atom pairs reorienting in the point-defect vicinity. A pair reorientation can occur in two cases: the first one is associated with a reversible process, in which, through energy delivery, atom pairs near the point defects can swap their positions and return to the initial state after the energy reduction, and in the second one, this displacement is permanent due to the major changes in the local space involving a minimum of three atoms. Both processes can occur in the same time and the curve

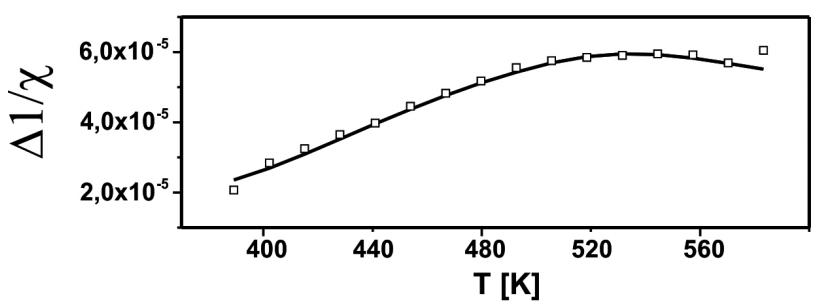

Figure 7: Theoretical magnetic-susceptibility disaccommodation curve (solid line) and experimental data for the $\mathrm{Fe}_{62} \mathrm{Co}_{10} \mathrm{Y}_{8} \mathrm{~B}_{20}$ alloy after solidification

Slika 7: Teoretična krivulja neprimerne magnetne občutljivosti (polna linija) in eksperimentalni podatki za zlitino $\mathrm{Fe}_{62} \mathrm{Co}_{10} \mathrm{Y}_{8} \mathrm{~B}_{20}$ po strjevanju observed in Figure 6 indicates the effect of the imposition of these two phenomena. The visible kink in the same temperature region as in the case of the stability of the initial-susceptibility curve (Figure 5) is presumably also caused by the relaxation processes. This phenomenon must therefore at least partially occur through the irreversible atomic-pair reorientation, clearly manifested between $325 \mathrm{~K}$ and $400 \mathrm{~K}$ (Figure 6). As the relaxation process of the material has to occur through the displacement of atoms into positions that lead to a lower total energy of the system, a part of these movements must therefore lead to the reorientation of atomic pairs visible as disaccommodation phenomena. Next, a numerical analysis of the disaccommodation curve was done (Figure 7).

The isochronal magnetic-susceptibility disaccommodation curve was numerically analyzed using the dependence given with Equation (1):

$$
\begin{aligned}
& \Delta\left(\frac{1}{x}\right)=\sum_{i=1}^{l} \int_{-3 \beta_{\tau i}}^{3 \beta_{\tau i}} \beta_{\tau}^{-1} \pi^{-1 / 2} \frac{I_{p i} T_{p i}}{T} . \\
& \left(e^{-\frac{t_{1}}{\tau_{m i} e^{z}}}-e^{-\frac{t_{2}}{\tau_{m i} e^{z}}}\right) e^{-\left(\frac{z}{\beta_{\tau i}}\right)^{2}} \mathrm{~d} z
\end{aligned}
$$

where the mean relaxation time $\tau_{m i}$ is given:

$\tau_{m i}=\tau \exp \left(-\frac{Q_{m i}}{k}\left(\frac{1}{T}-\frac{1}{T_{p i}}\right)\right)$

$\tau$ - the pre-exponential factor in the Arrhenius law, $I_{\mathrm{pi}}-$ the intensity of the $i^{\text {th }}$ process at temperature $T_{\mathrm{pi}}, Q_{\mathrm{mi}}-$ the mean activation energy, $\beta$ - the distribution width and $z=\ln \tau / \tau_{m i}$.

The results of the analysis of the disaccommodation curve in function of temperature, based on the above formula done using the least squares method is presented in Table 2.

Table 2: Results obtained from the numerical analysis of disaccommodation curve

Tabela 2: Rezultati, dobljeni iz numerične analize neustrezne krivulje

\begin{tabular}{|c|c|c|}
\hline$a$ & $1.095^{*} 10^{-7}$ & $\tau(\mathrm{s})$ \\
\hline$b$ & $-2.230^{*} 10^{-5}$ & \\
\hline$T_{\mathrm{p}}(\mathrm{K})$ & 433.20 & $2.62 \times 10^{-15}$ \\
\hline$I_{\mathrm{p}}$ & $5.223^{* 10^{-6}}$ & \\
\hline$Q(\mathrm{eV})$ & 1.378 & \\
\hline$\beta$ & 6.9368 & \\
\hline$T_{\mathrm{p}}(\mathrm{K})$ & 479.17 & $2.98 \times 10^{-15}$ \\
\hline$I_{\mathrm{p}}$ & $3.215^{*} 10^{-5}$ & \\
\hline$Q(\mathrm{eV})$ & 1.5189 & \\
\hline$\beta$ & 5.0638 & \\
\hline$T_{\mathrm{p}}(\mathrm{K})$ & 542.87 & $5.26 \times 10^{-15}$ \\
\hline$I_{\mathrm{p}}$ & $2.52 * 10^{-5}$ & \\
\hline$Q(\mathrm{eV})$ & 1.6942 & \\
\hline$\beta$ & 3.7668 & \\
\hline
\end{tabular}

The isochronal magnetic-susceptibility disaccommodation curve was decomposed into three elementary 
processes (peaks). The first peak with the maximum localized at $433 \mathrm{~K}$ has the lowest activation energy $(Q)$, the highest width $(\beta)$ and the highest intensity $\left(I_{\mathrm{p}}\right)$. Most of the elementary-pair-reconfiguration processes therefore require a minimum activation energy of $1.38 \mathrm{eV}$. An analysis of Table 2 reveals that the peak maximum temperature $\left(T_{\mathrm{p}}\right)$ increases together with the activation energy and relaxation time $\tau$. At the same time, the distribution width and process intensity decrease. This phenomena is probably related with the atomic mass (and also the radius) of the ingredients. Thus, atom pairs with a higher mass or a bigger size require more energy and time for the relaxation to occur. On this basis, it can be concluded that the first elementary process is mostly caused by boron (a radius of $82 \mathrm{pm}$, a weight of $10.8 \mathrm{u}$ ), the second process mainly involves Fe (r. $126 \mathrm{pm}$, w. $55.9 \mathrm{u})$ and Co (r. $125 \mathrm{pm}$, w. $58.7 \mathrm{u}$ ) and the last process, which requires the largest activation energy, is caused due to an increasing involvement of yttrium (r. $180 \mathrm{pm}$, w. $88.9 \mathrm{u}$ ) atoms. Obviously, due to the smallest size and weight of $\mathrm{B}$, this element probably has the largest share in each of the elementary processes, but it should be noted that the pair reorientation involving atoms with extreme size differences, tends to be irreversible.

\section{CONCLUSIONS}

In the radial cooling process, a good-quality bulk amorphous sample of the $\mathrm{Fe}_{62} \mathrm{Co}_{10} \mathrm{Y}_{8} \mathrm{~B}_{20}$ composition was prepared. Studies of its magnetic properties showed that despite a notably large yttrium share, it is possible to make the material to be rather soft $\left(H_{\mathrm{c}}=289 \mathrm{~A} / \mathrm{m}\right)$. Susceptibility studies showed that in terms of magnetic properties, the material is homogeneous. Simultaneously, magnetic-susceptibility disaccommodation studies clearly revealed a presence of point defects, which are responsible for the magnetization process in the Rayleigh area. Therefore, point defects must also be distributed uniformly across the entire volume of the material. The decomposition of the susceptibility disaccommodation curve in three elementary processes was sufficient to completely describe the pair reorientation, showing the dependence of the activation energy, intensity and relaxation time on the mass (and radius) of the elements involved in the reorientation process. At $H>0.4 H_{\mathrm{c}}$, in the approach to the ferromagnetic saturation area, the initial-magnetization-curve analysis, with respect to Kronmüller's theory, led to the conclusion that in the magnetization process, linear defects of the second type play the main role.

A detailed analysis of the parameters obtained on the basis of this theory showed that the defects of this type can be considered as swellings of voids, leading to an increase in the local density around them. On the other hand, as it is known, long-term annealing below the crystallization temperature leads to a decrease in dis- accommodation phenomena ${ }^{17}$ associated with the stress relaxation (due to the atom expansion) and defect diffusion to the sample's surface. There are no indications that the linear defects are not subjected to the same processes, leading to their decomposition into smaller point defects. At the same time, no increase in the intensity of disaccommodation phenomena is observed (directly related to the amount of point defects). This may suggest that the linear conglomerates of defects disappear because of collapse-like processes and not due to shredding. This is consistent with the conclusion about an increase in the structural stresses around the linear defects, pushing to fill the voids and, therefore, reduce the system energy. Considering that the range of the exchange interaction is smaller than the average size of a linear defect, the stress relaxation due to the annealing process should lead to a reduction in the number of defects, observed as a decrease in the $D_{\text {sp }}$ parameter.

\section{REFERENCES}

${ }^{1}$ M. G. Nabiałek, P. Pietrusiewicz, M. J. Dospiał, M. Szota, K. Błoch, K. Gruszka, K. Oźga, S. Garus, Effect of manufacturing method on the magnetic properties and formation of structural defects in $\mathrm{Fe}_{61} \mathrm{Co}_{10} \mathrm{Y}_{8} \mathrm{Zr}_{1} \mathrm{~B}_{20}$ amorphous alloy, Journal of Alloys and Compounds, 615 (2014) S1, 51-55, doi:10.1016/j.jallcom.2013. 12.163

${ }^{2}$ K. Błoch, M. Nabiałek, P. Pietrusiewicz, J. Gondro, M. Dośpiał, M. Szota, K. Gruszka, Time and Thermal Stability of Magnetic Properties in $\mathrm{Fe}_{61} \mathrm{Co}_{10} \mathrm{Y}_{8} \mathrm{Nb}_{1} \mathrm{~B}_{20}$ Bulk Amorphous Alloys, Acta Physica Polonica A, 126 (2014) 1, 108-109, doi:10.12693/ APhysPolA.126.108

${ }^{3} \mathrm{~K}$. Błoch, Structure and magnetic properties of bulk amorphous $\left(\mathrm{Fe}_{0.61} \mathrm{Co}_{0.10} \mathrm{Zr}_{0.025} \mathrm{Hf}_{0.025} \mathrm{~W}_{0.02} \mathrm{Ti}_{0.02} \mathrm{~B}_{0.20}\right)_{94} \mathrm{Y}_{6}$ alloy, Archives of Materials Science and Engineering, 64 (2013) 2, 97-102

${ }^{4}$ W. J. Botta, J. E. Berger, C. S. Kiminami, V. Roche, R. P. Nogueira, C. Bolfarini, Corrosion resistance of Fe-based amorphous alloys, Journal of Alloys and Compounds, 586 (2014) 1, 105-110, doi:10.1016/j.jallcom.2012.12.130

${ }^{5}$ Y. Han, C. T. Chang, S. L. Zhu, A. Inoue, D. V. Louzguine-Luzgin, E. Shalaan, F. Al-Marzouki, Fe-based soft magnetic amorphous alloys with high saturation magnetization above $1.5 \mathrm{~T}$ and high corrosion resistance, Intermetallics, 54 (2014), 169-175, doi:10.1016/j.intermet.2014.06.006

${ }^{6}$ P. Pietrusiewicz, M. Nabiałek, M. Szota, M. Dośpiał, K. Gruszka, Influence of Low Temperature Annealing on the Magnetic and Structural Properties of $\mathrm{Fe}_{61} \mathrm{Co}_{10} \mathrm{Y}_{8} \mathrm{~W}_{1} \mathrm{~B}_{20}$ Alloy, Acta Physica Polonica A, 126 (2014) 1, 110-111, doi:10.12693/APhysPolA.126.110

${ }^{7}$ K. Sobczyk, J. Świerczek, J. Gondro, J. Zbroszczyk, W. Ciurzyńska, J. Olszewski, P. Brągiel, A. Łukiewska, J. Rzącki, M. Nabiałek, Microstructure and some magnetic properties of bulk amorphous $\left(\mathrm{Fe}_{0.61} \mathrm{Co}_{0.10} \mathrm{Zr}_{0.025} \mathrm{Hf}_{0.025} \mathrm{Ti}_{0.02} \mathrm{~W}_{0.02} \mathrm{~B}_{0.20}\right)_{100-\mathrm{x}} \mathrm{Y}_{\mathrm{x}}(x=0,2,3$ or 4$)$ alloys, Journal of Magnetism and Magnetic Materials, 324 (2012), 540-549, doi:10.1016/j.jmmm.2011.08.038

${ }^{8}$ H. Kronmüller, Theory of magnetic after-effects in ferromagnetic amorphous alloys, Philosophical Magazine B: Physics of Condensed Matter, 48 (1983) 2, 127-150, doi:10.1080/13642818308226466

${ }^{9}$ H. Kronmüller, Micromagnetism and microstructure of amorphous alloys, Journal of Applied Physics, 52 (1981), 1859-1864, doi:10.1063/1.329552

${ }^{10}$ M. Hirscher, R. Reisser, R. Würschum, H. E. Schaefer, H. Kronmüller, Magnetic after-effect and approach to ferromagnetic saturation in nanocrystalline iron, Journal of Magnetism and Magnetic Materials, 146 (1995), 117-122, doi:10.1016/0304-8853(94)01643-7 


\section{K. GRUSZKA: ANALYSIS OF THE STRUCTURAL-DEFECT INFLUENCE ON THE MAGNETIZATION PROCESS ...}

${ }^{11}$ H. Kronmüller, Micromagnetism in Amorphous Alloys, IEEE Transactions on Magnetics, 15 (1979) 5, 1218-1225, doi:10.1109/ TMAG.1979.1060343

${ }^{12}$ N. Lenge, H. Kronmüller, Low temperature magnetization of sputtered amorphous Fe-Ni-B films, Physica Status Solidi A, 95 (1986), 621-633, doi:10.1002/pssa.2210950232

${ }^{13}$ D. Goll, Handbook of Magnetism and Advanced Magnetic Materials 2, J. Wiley \& Sons, 2007, doi: 10.1002/9780470022184.hmm203

${ }^{14}$ M. Pajda, J. Kudrnovsky, I. Turek, V. Drchal, P. Bruno, Ab initio calculations of exchange interactions, spin-wave stiffness constants, and Curie temperatures of Fe, Co, and Ni, Physical Review B, 64 (2001) 17, 174402: 1-9, doi:10.1103/PhysRevB.64.174402
${ }^{15}$ R. B. Muniz, J. d'Albuquerque e Castro, E. da Silva, Spin wave stiffness constant of iron, Journal de Physique Colloques, 49 (1988) C8, 89-90, doi:10.1051/jphyscol:1988831

${ }^{16}$ M. Nabiałek, P. Pietrusiewicz, M. Dośpiał, M. Szota, J. Gondro, K. Gruszka, A. Dobrzańska-Danikiewicz, S. Walters, A. J. Bukowska, Influence of the cooling speed on the soft magnetic and mechanical properties of $\mathrm{Fe}_{61} \mathrm{Co}_{10} \mathrm{Y}_{8} \mathrm{~W}_{1} \mathrm{~B}_{20}$ amorphous alloy, Alloys and Compounds, 615 (2015), 56-60, doi:10.1016/j.jallcom.2013.12.236

${ }^{17}$ M. Hasiak, W. H Ciurzyńska, Y. Yamashiro, Microstructure and some magnetic properties of amorphous and nanocrystalline $\mathrm{Fe}-\mathrm{Cu}-\mathrm{Nb}-\mathrm{Si}-\mathrm{B}$ alloys, Materials Science and Engineering A, 293 (2000) 1-2, 261-266, doi:10.1016/S0921-5093(00)01030-3 